\title{
Transforming Growth Factor- $\beta$ Blocks Myelination but Not Ensheathment of Axons by Schwann Cells in vitro
}

\author{
Véronique Guénard, Lisa A. Gwynn, and Patrick M. Wood \\ The Miami Project to Cure Paralysis and Department of Neurological Surgery, University of Miami School of Medicine, \\ Miami, Florida 33136
}

\begin{abstract}
Mechanisms regulating Schwann cell differentiation into a myelinating or a mature nonmyelinating phenotype during development are poorly understood. Humoral factors such as members of the transforming growth factor- $\beta$ (TGF- $\beta$ ) family, which are found in the developing and adult mammalian nervous system and are known to affect cell differentiation, could be involved. We tested the effects of TGF- $\beta$ isoforms on the ensheathment and myelination of dorsal root ganglion (DRG) neurons by Schwann cells in vitro. Rat embryonic DRG neurons and Schwann cells from the sciatic nerve were isolated, purified, and recombined. In serum-free conditions, TGF- $\beta$ blocked both Schwann cell myelination and the expression of the myelin-related molecules galactocerebroside, $P_{0}$, myelin-associated glycoprotein, and $m y-$ elin basic protein. In contrast, the expression of molecules characteristic of mature nonmyelinating Schwann cells, including neural-cell adhesion molecule, L1, and nerve growth factor receptor, was maintained when compared to Schwann cells in nondifferentiated cultures. Notably, the expression of glial fibrillary acidic protein, which is expressed only in mature nonmyelinating Schwann cells in vivo, was increased 10 -fold in our cultures by TGF- $\beta$. Electron microscopic analysis indicated that in the presence of TGF- $\beta$, basal lamina deposition by Schwann cells was slightly increased. Most importantly, many axons in TGF- $\beta$-treated cultures received ensheathment typical of mature nonmyelinated nerves. These effects of TGF- $\beta$ were partially reversed by specific neutralizing anti-TGF- $\beta$ antibodies. We interpret these results as evidence that TGF- $\beta$ regulates Schwann cell differentiation in vitro by blocking the expression of the myelinating
\end{abstract}

\footnotetext{
Received Mar. 7, 1994; revised June 20, 1994; accepted June 23, 1994.

This work was supported by NIH Grant NS 28059 and National Multiple Sclerosis Society Grant RG 2210-A-2 to P.M.W., and rescarch funds from The Miami Project to Cure Paralysis. We are grateful to Dr. John Klose for his help with the statistical analysis; Anna Gomez, LeeAnne Lipson, Margaret Bates, and Francisco Cruz for excellent technical help; and Robert Camarina and Christopher Hoey for photographic assistance. The monoclonal $217 \mathrm{c}$ and polyclonal $\mathrm{P0}$ and MBP antibodies were generous gifts from Dr. J. deVellis (University of California at Los Angeles, CA), Dr. J. Brockes (Ludwig Center for Cancer Research, London, England), and Dr. John Trotter (Washington University, St. Louis, MO), respectively. The polyclonal N-CAM and L1 antibodies and hybridoma cell lines producing the monoclonal antibodies $\mathrm{O} 4, \mathrm{O} 1$, and MAG were generous gifts from Dr. M. Schachner (Swiss Federal Institute of Technology, Zurich, Switzerland).

Correspondence should be addressed to Patrick M. Wood, Ph.D., The Miami Project to Cure Paralysis, University of Miami School of Medicine, $1600 \mathrm{NW}$ 10th Avenue, R-48, Miami, FL 33136.

Copyright (C) 1995 Society for Neuroscience $0270-6474 / 95 / 150419-10 \$ 05.00 / 0$
}

phenotype and promoting the development of the nonmyelinating phenotype.

[Key words: transforming growth factor- $\beta$, neuron, Schwann cell, differentiation, myelination]

Mechanisms regulating Schwann cell proliferation, basal lamina synthesis, and final differentiation in the peripheral nervous system (PNS) during development are poorly understood. The end point of Schwann cell differentiation is postmitotic commitment to either a myelinating or a mature nonmyelinating phenotype (Webster and Favilla, 1984). These phenotypes are distinctly different with respect to morphology and the expression of various surface and intracellular molecules (Jessen and Mirsky, 1991). Studies suggest that unknown molecular signals determining the Schwann cell phenotype may originatc from both neuronal and non-neuronal cells (Aguayo et al., 1976; Weinberg and Spencer, 1976; Voyvodic, 1989; Obremski et al., 1993).

Recent studies indicate that members of the transforming growth factor- $\beta$ (TGF- $\beta$ ) family are involved in processes regulating cellular function. TGF- $\beta$ belongs to a family of homologous polypeptides with multiple effects on cell proliferation, differentiation, and extracellular matrix formation (reviewed in Barnard et al., 1990; Massagué, 1990; Sporn and Roberts, 1992). For instance, the action of TGF- $\beta$ on cell proliferation and differentiation in vitro varies from inhibition to stimulation, depending on the cell type, tissue culture conditions, and growth factors present. Isoforms of TGF- $\beta$ have been detected in both the developing and adult mammalian central (CNS) and peripheral nervous systems (Flanders et al., 1991; Unsicker et al., 1991; Scherer et al., 1993); more specifically, TGF- $\beta$ has been localized in certain neurons in the CNS, dorsal root ganglion (DRG) neurons, astrocytes, and Schwann cells, suggesting a possible role for TGF- $\beta$ in the regulation of glial cell function. Insights on the possible role of TGF- $\beta$ in Schwann cell development come from in vitro studies showing that TGF- $\beta$ is a mitogen for Schwann cells (Eccleston et al., 1989; Ridley et al., 1989; Schubert, 1992), inhibits cAMP-induced $P_{0}$ mRNA expression, and downregulates nerve growth factor receptor $\mathrm{mRNA}$ expression in Schwann cells (Mews and Meyer, 1993). These effects were demonstrated, however, in cultures lacking neurons. There has thus been a need for an in vitro model that more closely resembles in vivo systems and in which the influence of TGF- $\beta$ on Schwann cell differentiation and on the myelination on axons could be tested.

In the absence of exogenous mitogens, Schwann cells recom- 
bined with neurons proliferate, secrete extracellular matrix components, produce basal lamina, and form myelin sheaths (Wood and Bunge, 1975; Bunge et al., 1986, 1989; Eldridge et al., 1989; Kleitman et al., 1991). In the present study we isolated, purified, and recombined neurons and Schwann cells in vitro and tested the effects of TGF- $\beta$ isoforms on the myelination of DRG axons by Schwann cells in serum-free conditions. We report that TGF- $\beta$ blocked the formation of myelin sheaths by Schwann cells; these inhibitory effects were partially neutralized by specific antibodies to TGF- $\beta$. Furthermore, in the presence of TGF- $\beta$, the expression of myelin-related molecules was blocked. However, the expression of molecules characteristic of nonmyelinating Schwann cells was maintained or increased, as in the case of glial fibrillary acidic protein expression, when compared to conditions allowing the growth but not the differentiation of the Schwann cells. Finally, the pattern of axonal ensheathment in TGF- $\beta$-treated cultures resembled that seen in adult nonmyelinated nerves. This pattern of nonmyelinating ensheathment was rarely observed in control cultures. These results indicate that TGF- $\beta$ affects specific events of Schwann cell differentiation in vitro and may be involved in processes inducing the mature nonmyelinating Schwann cell phenotype.

\section{Materials and Methods}

\section{Preparation of purified cell cultures}

Neuronal cultures. Cultures of purified dissociated dorsal root ganglion (DRG) neurons were obtained as previously reported (Bunge et al., 1983; Kleitman et al., 1991). Briefly, DRG were excised from E15 SpragueDawley rats (Charles River Labs, Wilmington, MA), trypsinized, and mechanically dissociated; the cell suspension thus obtained was plated as a drop onto ammoniated rat tail collagen-coated Aclar (Allied Signal, Pottsville, PA) coverslips in Eagle's Minimal Essential Medium (EMEM, GIBCO Labs, Long Island, NY) supplemented with $10 \%$ heat-inactivated human placental serum (HPS), crude nerve growth factor (NGF, $50 \mathrm{ng} / \mathrm{ml})$, glucose (0.4\%; w:v), and L-ascorbate acid (10 $\mu \mathrm{g} / \mathrm{ml}$; Sigma). Contaminating non-ncuronal cells were eliminated by treatment with fluorodeoxyuridine ( $10 \mu \mathrm{M}$; Sigma, St. Louis, MO) in serum-free medium consisting of EMEM with glucose $(0.4 \%$, w:v), NGF $(50 \mathrm{ng} / \mathrm{ml})$, insulin ( $50 \mu \mathrm{g} / \mathrm{ml}$; Sigma), progesterone ( $20 \mathrm{pM}$; Sigma), putrescine (100 $\mu \mathrm{M}$; Sigma), sodium selenite (30 pM; Pflatz and Bauer, Waterbury, CT), and transferrin $(10 \mu \mathrm{g} / \mathrm{ml}$; Jackson Immunoresearch Labs, West Grove, CT). Cultures were then maintained in EMEM containing 5\% HPS, NGF $(50 \mathrm{ng} / \mathrm{ml})$, and glucose $(0.4 \%$; w:v $)$ at $35^{\circ} \mathrm{C}$ with $5 \% \mathrm{CO}_{2}$.

Schwann cell cultures. Schwann cells were prepared from the sciatic nerve of E21-P1 Sprague-Dawley rats according to the technique of Brockes et al. (1979). Briefly, the cell suspension resulting from enzymatically and mechanically dissociated sciatic nerves was plated onto poly-L-lysine-coated Petri dishes in Dulbecco's Modified Eagles Medium (DMEM, GIBCO Labs) supplemented with $10 \%$ fetal bovine serum (FBS; Hyclone Laboratories, Logan, UT) (D medium). Contaminating fibroblasts were eliminated by treatments with the antimitotic agent cytosine arabinoside $\left(10^{-5} \mathbf{M}\right.$; Sigma) and antibody-complementmediated cell lysis using the monoclonal anti-Thy 1.1 antibody (used as an undiluted hybridoma culture supernatant; American Tissue Culture Collection, ATCC) and rabbit complement (Sigma). Cells were allowed to proliferate in $\mathrm{D}$ medium supplemented with pituitary extract (10 $\mu \mathrm{g} / \mathrm{ml}$; Sigma) and forskolin (2 $\mu \mathrm{M}$; Sigma) (Porter et al., 1986). Cultures were kept at $37^{\circ} \mathrm{C}$ with $5 \% \mathrm{CO}_{2}$.

The purity of the Schwann cell cultures was determined by immunostaining for S-100 (Dakopatts, Santa Barbara, CA), a Schwann cell marker, and Thy-1.1, a fibroblast marker. After labeling, the cultures were mounted onto glass slides using Citifluor (University College London, England) containing the fluorescent nuclear dye Hoechst 33342 (5 $\mu \mathrm{M}$; Sigma). The percentage of S-100-positive and Thy-1-positive cells was determined on a Zeiss Universal microscope equipped with epifluorescence at a final magnification of $400 \times$. An average of 500 cells was counted for each immunostain. Cultures were $98.7 \%$ pure in Schwann cells and contained $1.3 \%$ fibroblasts.
Neuron-Schwann cell cultures. Schwann cells were trypsinized, rinsed, counted using a hemocytometer, and resuspended in EMEM supplemented with $10 \%$ FBS, NGF (50 ng/ml), and glucose $(0.4 \%$; w:v) (E medium); 70,000 Schwann cells were added per culture. These cultures were maintained in $\mathbf{E}$ medium for 12-15 $\mathrm{d}$ to allow the cocultures to become fully populated with Schwann cells.

\section{Methods to determine the effects of $T G F_{-} \beta$ on Schwann cell myelination}

To determine the influence of both TGF- $\beta 1$ and TGF- $\beta 2$ on Schwann cell myelination, cultures fully populated with Schwann cells were rinsed with serum-free myelinating medium that consisted of EMEM supplemented with glucose $(0.4 \%$, w:v), NGF $(50 \mathrm{ng} / \mathrm{ml})$, insulin $(50 \mu \mathrm{g} / \mathrm{ml})$, progesterone (20 pM), putrescine $(100 \mu \mathrm{M}$ ) ), sodium selenite (30 pM), transferrin $(10 \mu \mathrm{g} / \mathrm{ml})$, laminin (50 $\mathrm{nM}$; Collaborative Biomedical Products), L-ascorbic acid (10 $\mu \mathrm{g} / \mathrm{ml})$, and bovine serum albumin (BSA; $0.25 \%$; Sigma) (Eldridge et al., 1989) (M medium). Cultures received TGF- $\beta 1$ or TGF- $\beta 2(0,1$, and $10 \mathrm{ng} / \mathrm{ml}$; Red Systems, Minneapolis, MN). Blocking experiments were performed by adding TGF- $\beta 1$ or TGF$\beta 2(\mathrm{lng} / \mathrm{ml})$ combined with anti-TGF- $\beta 1$ or anti-TGF- $\beta 2$ antibody $(10$ $\mu \mathrm{g} / \mathrm{ml}$; Red Systems), respectively, or TGF- $\beta 2(10 \mathrm{ng} / \mathrm{ml})$ combined with anti-TGF- $\beta 2$ antibody $(50 \mu \mathrm{g} / \mathrm{ml})$ to $\mathrm{M}$ medium. The medium was changed every other day and the cultures were maintained in $\mathrm{M}$ medium for $9 \mathrm{~d}$ at $37^{\circ} \mathrm{C}$ with $5 \% \mathrm{CO}_{2}$. To quantitate the amount of myelin in the cultures, cultures were stained with Sudan black according to the method reported by Wood and Williams (1984). The amount of myelin in duplicate cultures from each condition per experiment was detcrmined using an Olympus light microscope at a final magnification of $200 \times$. Briefly, using a 100 square eyegrid piece, the number of myelin segments in 30 fields selected by stage coordinates was evaluated; the numbers were then averaged, giving an estimate of the amount of myelin per field (Guénard et al., 1994). The percentage of inhibition of myelination was defined as one minus the ratio of the number of myelin segments in TGF- $\beta$-treated cultures over the number of myelin segments in control cultures, times 100 . The percentage of neutralization induced by anti-TGF- $\beta$ antibody treatment was determined as 100 times the ratio of the difference in percentage of inhibition between cultures treated with TGF- $\beta$ and cultures treated with anti-TGF- $\beta$ antibody divided by the percentage of inhibition induced by TGF- $\beta$.

Methods to determine if the effects of TGF- $\beta$ on Schwann cell myelination are reversible. To determine if the effects of TGF- $\beta$ on Schwann cell myelination were reversible, neuronal cultures fully populated with Schwann cells were treated with M medium containing TGF- $\beta 2(10 \mathrm{ng} /$ $\mathrm{ml}$ ) for an initial period of $9 \mathrm{~d}$. The cultures were then maintained for an additional $14 \mathrm{~d}$ period under one of the following three conditions. Cultures were fed with (1) TGF- $\beta 2$-free $M$ medium, (2) $M$ medium containing TGF- $\beta 2(10 \mathrm{ng} / \mathrm{ml})$, or (3) M medium containing anti-TGF$\beta 2$ antibody $(50 \mu \mathrm{g} / \mathrm{ml})$. Treatment was performed with antibody to TGF- $\beta 2$ to determine if TGF- $\beta 2$ remaining as a residue, possibly bound to the extracellular matrix during the first treatment phase, could still exert an inhibitory effect on myelination. As an additional control some cultures were first maintained for $9 \mathrm{~d}$ in $\mathrm{E}$ medium, which does not support myelination, and then switched for the last $14 \mathrm{~d}$ to $\mathrm{M}$ medium with or without anti-TGF- $\beta 2$ antibody $(50 \mu \mathrm{g} / \mathrm{ml})$. The feeding medium was changed every other day. $\Lambda t$ the end of the treatment period the cultures were fixed, stained with Sudan black, and the amount of myelin per culture evaluated as reported above. Although TGF- $\beta 1$ and TGF$\beta 2$ interact with the same cell surface receptors (Barnard et al., 1990), we observed the stronger response of Schwann cells to TGF- $\beta 2$ than to TGF- $\beta 1$; we thus chose TGF- $\beta 2$ for these experiments.

Immunostaining for myelin-related molecules. To further characterize the effects of TGF- $\beta$ on myelination we studied the expression of various myelin-related molecules in Schwann cells in neuron-Schwann cell cultures on the day the medium was switched from growth (E medium) to myelinating ( $M$ medium) conditions (i.e., day 0 ) and after maintenance for $9 \mathrm{~d}$ under myelinating conditions with or without TGF- $\beta 2(10 \mathrm{ng} /$ $\mathrm{ml}$ ). Immunostaining with the $\mathrm{O} 4$ monoclonal antibody that recognizes an uncharacterized molecule present on all immature neuron-associated Schwann cells was first performed (Morgan et al., 1991). Differentiation was then characterized by evaluating the expression of galactocerebroside (GC), a myelin glycolipid expressed at the onset of myelination (Wood et al., 1990a; assessed using anti-O1 antibody; Bansal et al., 1981; Sommer and Schachner, 1981) and the myelin proteins $P_{0}$, my- 
elin-associated glycoprotein (MAG), and myelin basic protein (MBP) in Schwann cells (Jessen and Mirsky, 1991).

Double immunostaining with antibodies to $\mathrm{O} 4$ and $\mathrm{O} 1$ was performed on live cultures as reported previously (Guénard et al., 1994). For MAG immunostaining, live cultures were blocked, incubated for 30 min each at $4^{\circ} \mathrm{C}$ with monoclonal anti-MAG antibody supernatant followed by rhodamine-conjugated goat anti-mouse antibody (1:50, Cappel/Organon Teknika), fixed, and mounted (Guénard et al., 1994). For P0 and MBP immunostaining, cultures were fixed, permeabilized with Triton $\mathrm{X}-100$ in fixative followed by acetone, blocked, incubated for $30 \mathrm{~min}$ each at $4^{\circ} \mathrm{C}$ with anti- $\mathrm{P}_{0}(1: 100)$ or anti-MBP $(1: 50)$ antibody followed by fluoresccin-conjugated goat anti-rabbit antibody (1:100; Cappel/Organon-Teknika) or fluorescein-conjugated rabbit anti-goat antibody (1: 100; Cappel/Organon-Teknika), respectively, and mounted.

Electron microscopy. Control cultures and cultures treated with TGF$\beta 2(10 \mathrm{ng} / \mathrm{ml})$ were processed for transmission electron microscopy (TEM). Cultures were postfixed in $1 \% \mathrm{OsO}_{4}$ for $1 \mathrm{hr}$, dehydrated, and embedded in Polybed (Polysciences Inc., Warrington, PA) (Bunge et al., 1989). Two areas containing neurite fascicles and Schwann cells were chosen per culture per condition, scored, excised, and mounted onto blank plastic blocks; one culture per condition taken from two experiments was sampled. Ultrathin sections were obtained, mounted, and stained with Reynold's lead citrate and uranyl acetate. Areas were examined for the presence of basal lamina, axonal ensheathment by Schwann cells, and the formation of axon:Schwann cell 1:1 relationships, using a Philips CT-10 transmission elcctron microscope. An axon was considered ensheathed if all its surface visible in the cross section of the micrograph was in apposition with Schwann cell cytoplasm. An axon was considered to be in a 1:1 relationship with a Schwann cell if it appeared completely isolated and surrounded by a single Schwann cell.

\section{Methods for immunostaining to detect markers for nonmyelinating Schwann cells}

To characterize the effects of TGF- $\beta$ on Schwann cell differentiation, cultures were immunostained, on the day differentiation was initiated (i.e., day 0$)$ or after $9 \mathrm{~d}$ in $\mathrm{M}$ medium with or without TGF- $\beta 2(10 \mathrm{ng} /$ $\mathrm{ml}$ ), with antibodies against antigens characteristic of mature nonmyelinating Schwann cells (Mirsky et al., 1986; Jessen and Mirsky, 1991; Martini, 1994). Specifically, antibodies against neural-cell adhesion molecule (N-CAM), L1, nerve growth factor receptor (NGFr) (assessed using anti-217c antibody; Kumar et al., 1990), and glial fibrillary acidic protein (GFAP) were used. For $L 1$ and $217 \mathrm{c}$ immunostaining, live cultures were blocked, incubated for $30 \mathrm{~min}$ each at $4^{\circ} \mathrm{C}$ with monoclonal anti-L1 $(500 \mu \mathrm{g} / \mathrm{ml})$ or anti-217c $(1: 100)$ antibody followed by rhodamine-conjugated goat anti-mouse antibody (1:50, Cappel/Organon Teknika), fixed, and mounted (Guénard et al., 1994). For N-CAM and GFAP immunostaining, cultures were fixed, permeabilized with Triton $X-100$ in fixative followed by acetone, blocked, incubated for $30 \mathrm{~min}$ each at $4^{\circ} \mathrm{C}$ with anti-N-CAM $(1: 4)$ or anti-GFAP $(1: 100$; Biomedical Technologies Inc., Stoughton, MA) antibody followed by fluoresceinconjugated goat anti-rabbit antibody (1:100; Cappel/Organon-Teknika), and mounted.

Since GFAP is a marker for mature nonmyelinating Schwann cells (Jessen and Mirsky, 1991), an cstimatc of the percentage of Schwann cells that expressed the nonmyelinating phenotype was evaluated in duplicate GFAP-immunostained control and TGF- $\beta 2-$ treated cultures. Using a 100 square grid, the total number of Schwann cells (Hoechstpositive cells) and the number of GFAP-positive Schwann cells in fields taken outside the initial neuronal seeding drop were randomly counted; an average of 500 cells were examined in each culture. Counting was not performed in the drop area due to the high density of the Schwann cell population. The percentage of GFAP-positive Schwann cells was determined as 100 times the ratio of the number of GFAP-positive Schwann cells to the number of Hoechst-positive Schwann cells.

\section{Statistics}

Data are presented as mean \pm SEM. One-way analysis of variance (between conditions) followed by Tukey HSD post-test comparisons between mean individual cells was used. Statistical analysis was performed using a commercially available software program (StatSoft Inc., Tulsa, OK). Statistical significance was accepted for $p<0.05$.
Table 1. Inhibition of myelination by TGF- $\beta$ and neutralizing effects of anti-TGF- $\beta$ antibodies

\begin{tabular}{lcll} 
Condition & $\begin{array}{l}\text { Amount of } \\
\text { myelin/field }\end{array}$ & $\begin{array}{l}\text { \% Inhibi- } \\
\text { tion }\end{array}$ & $\begin{array}{l}\text { \% Neutrali- } \\
\text { zation }\end{array}$ \\
\hline $\begin{array}{l}\text { Control } \\
\text { TGF- } \beta 1\end{array}$ & $75.3 \pm 11.0$ & \\
$1 \mathrm{ng} / \mathrm{ml}$ & $28.0 \pm 6.5^{*}$ & 62.8 & \\
$10 \mathrm{ng} / \mathrm{ml}$ & $0.3 \pm 0.3^{*}$ & 96.9 & \\
TGF- $\beta 1+$ anti-TGF- $\beta-1$ antibody & & \\
$1 \mathrm{ng} / \mathrm{ml}-10 \mu \mathrm{g} / \mathrm{ml}$ & $34.3 \pm 3.5^{*}$ & & 12.7 \\
Control & $60.0 \pm 17.0$ & & \\
TGF- $\beta 2$ & & \\
$1 \mathrm{ng} / \mathrm{ml}$ & $14.8 \pm 1.6^{*}$ & 75.3 & \\
$10 \mathrm{ng} / \mathrm{ml}$ & $0^{*}$ & 100 & \\
$\mathrm{TGF}-\beta 2+$ anti-TGF- $\beta-2$ antibody & & \\
$1 \mathrm{ng} / \mathrm{ml}-10 \mu \mathrm{g} / \mathrm{ml}$ & $40.2 \pm 8.6^{* * * *}$ & \\
$10 \mathrm{ng} / \mathrm{ml}-50 \mu \mathrm{g} / \mathrm{ml}$ & $39.5 \pm 8.5^{a}$ & & 65.2 \\
\hline
\end{tabular}

Myelin segments were counted on Sudan black-stained whole-mounted cultures $9 \mathrm{~d}$ after switching to myelinating medium. Values shown are means and SEM of determinations on duplicate cultures taken from three (TGF- $\beta 1$ ) and four (TGF$\beta 2$ ) experiments. One-way ANOVA followed by Tukey post-test comparisons was used to test significance between pairs of means. Statistical significance $(p<0.05)$ is indicated between control and treated cultures (") and between cultures treated with TGF- $\beta$ alone or combined with anti-TGF- $\beta$ antibody (").

a Statistics not done since data are taken from duplicate cultures obtained from only two experiments.

\section{Results}

Cultures consisted of dissociated sensory DRG neurons scattered in the center of the cultures and sending out neurites toward the periphery. Purified populations of Schwann cells added to these cultures either aligned along the bare neurites or, when not in contact with a neurite, attached to the collagen substratum. Within $24 \mathrm{hr}$ after adding the Schwann cells to the neurons, Schwann cells started to proliferate in response to the neuronal mitogen (Wood and Bunge, 1975; Salzer et al., 1980; Ratner et al., 1988). By 12-15 d the Schwann cells covered the entire area occupied by axons, being aligned along the neurites and having their characteristic spindle shape. These cultures were considered "fully populated" with Schwann cells. Sudan black staining indicated that no myelin segments were present in the cultures (data not shown). Previous examination of similar cultures by electron microscopy had shown few interactions between Schwann cells and axons; Schwann cells occasionally sending out short processes were located near groups of axons (Eldridge et al., 1989). Phenotypic characterization of these Schwann cells by immunostaining indicated that prior to initiating treatment with TGF- $\beta$, neurite-associated Schwann cells were $\mathrm{O} 4, \mathrm{O} 1, \mathrm{~N}-\mathrm{CAM}, \mathrm{L} 1$, and $217 \mathrm{c}$ positive, and $\mathrm{P} 0$ and GFAP negative (data not shown). In addition, Schwann cells have been previously shown to be MAG negative under similar conditions (Fernandez-Valle et al., 1993).

\section{$T G F-\beta$ induces flattening of neuron-associated Schwann cells}

An early indication that TGF- $\beta$ may modify Schwann cell function was indicated by changes in morphology observed following the onset of TGF- $\beta$ treatment. Neuron-associated Schwann cells in TGF- $\beta 1$ - or TGF- $\beta 2$-treated cultures maintained under myelinating conditions exhibited a flattened, fibroblast-like morphology (Fig. $1 B$ ); these Schwann cells did not exhibit the characteristic spindle shape observed in control cultures (Fig. 1 $A$ ). 



Figure 1. Light micrographs $(A-C)$ of Sudan black-stained areas taken from neuron-Schwann cell cultures maintained for $9 \mathrm{~d}$ in myelinating medium under control conditions $(A)$, or after treatment with TGF- $\beta 2$ $(10 \mathrm{ng} / \mathrm{ml})$ alone $(B)$ or combined with anti-TGF- $\beta 2(50 \mu \mathrm{g} / \mathrm{ml})(C)$. Note that myelin segments (arrows) are virtually absent from cultures treated with TGF- $\beta 2$ and that the Schwann cell morphology changes from a spindle shape in the control culture to a fibroblast-like shape in
Table 2. Nonreversibility of the inhibition of myelination by TGF- $\beta 2$

\begin{tabular}{lll} 
Condition & Experiment 1 & Experiment 2 \\
\hline $\begin{array}{l}\mathrm{M}+\mathrm{TGF}-\beta 2 \rightarrow \mathrm{M} \\
\mathrm{M}+\mathrm{TGF}-\beta 2 \rightarrow \mathrm{M}\end{array}$ & $1.6 \pm 0.7$ & $0.4 \pm 0.1$ \\
$\quad+\mathrm{TGF}-\beta 2$ & $0.4 \pm 0.2$ & $0 \pm 0$ \\
$\mathrm{M}+\mathrm{TGF}-\beta 2 \rightarrow \mathrm{M}$ & & \\
$\quad+$ anti-TGF- $\beta 2$ antibody & $1.5 \pm 0.5$ & $2.1 \pm 0.4$ \\
$\mathrm{E} \rightarrow \mathrm{M}$ & $69.3 \pm 0.9$ & 10.1 \\
$\mathrm{E} \rightarrow \mathrm{M}+$ anti-TGF- $\beta 2$ antibody & $64.7 \pm 10.5$ & 8.2
\end{tabular}

Myelin segments were counted on Sudan black-stained whole-mounted cultures maintained for $9 \mathrm{~d}$ in $\mathrm{M}$ medium with TGF- $\beta 2(10 \mathrm{ng} / \mathrm{ml})$ followed by an additional $14 \mathrm{~d}$ in $\mathrm{M}$ medium with or without TGF- $\beta 2(10 \mathrm{ng} / \mathrm{ml})$ or anti-TGF- $\beta 2$ antibody $(50 \mu \mathrm{g} / \mathrm{ml})$ (see Materials and Methods). Additional control cultures were first maintained for $9 \mathrm{~d}$ in $\mathrm{E}$ medium and then switched to $\mathrm{M}$ medium with or without anti-TGF- $\beta 2$ antibody $(50 \mu \mathrm{g} / \mathrm{ml})$. Values shown are means and SEM of determinations on single to triplicate cultures.

Such morphological changes were observed less frequently in cultures incubated with both TGF- $\beta 1$ or TGF- $\beta 2$ and their respective antibodies (Fig. 1C).

\section{$T G F-\beta$ blocks Schwann cell myelination in a nonreversible manner}

To test the effects of TGF- $\beta$ on Schwann cell myelination, serial dilutions of TGF- $\beta 1$ and TGF- $\beta 2$ were assayed for their ability to affect the formation of myelin, initiated in serum-free conditions by the addition of laminin and ascorbic acid (Eldridge et al., 1989). Myelin was evaluated on Sudan black-stained cultures $9 \mathrm{~d}$ after switching neuron-Schwann cell cultures to $\mathrm{M}$ medium. Data from several experiments show that both TGF$\beta 1$ and TGF- $\beta 2$ blocked Schwann cell myelination on DRG axons in a dose-dependent manner (Fig. 1, Table 1). The highest effects were observed at a dose of $10 \mathrm{ng} / \mathrm{ml} \mathrm{TGF}-\beta 1$ or TGF$\beta 2$, which blocked myelination by $96 \%$ and $100 \%$, respectively. These inhibitions were partially neutralized by treatment with appropriate anti-TGF- $\beta$ antibodies (Fig. 1C). Anti-TGF- $\beta 2$ antibody at a dose of $50 \mu \mathrm{g} / \mathrm{ml}$ neutralized the completely inhibitory effect of $10 \mathrm{ng} / \mathrm{ml} \mathrm{TGF}-\beta 2$ by $65.8 \%$. Anti-TGF- $\beta 1$ and anti-TGF- $\beta 2$ antibodies at a lower dose $(10 \mu \mathrm{g} / \mathrm{ml})$ neutralized the inhibitory effects of $1 \mathrm{ng} / \mathrm{ml}$ TGF- $\beta 1$ and TGF- $\beta 2$ by $12.7 \%$ and $56.2 \%$, respectively.

To determine if the inhibition of myelination by TGF- $\beta$ was reversible, we performed an experiment in which cultures were treated with TGF- $\beta$ and subsequently treated with TGF- $\beta$-free medium. As expected, very few segments of myelin formed in cultures kept for the entire period in TGF- $\beta$-containing medium (Table 2). Somewhat surprisingly, myelin did not form in TGF$\beta$-treated cultures that were shifted to medium lacking TGF- $\beta$ for the final $14 \mathrm{~d}$ period (Table 2). There was no difference in the average number of myelin segments per field between these two culture groups, respectively averaging 0.2 and 1.0 . The normal value for this period averages 35 myelin segments per field. Furthermore, the inhibition of myelination by TGF- $\beta$ was not reversed by removal of TGF- $\beta$ and treatment with anti-TGF- $\beta$ antibody during the final $14 \mathrm{~d}$ period (Table 2); an average of 1.8 segments of myelin per field was observed in these cultures. This indicates that the sustained inhibition of myelination seen

the TGF- $\beta 2$-treated culture. These effects are reversed by treatment with anti-TGF- $\beta 2$ antibody. Bar, $50 \mu \mathrm{m}$. 

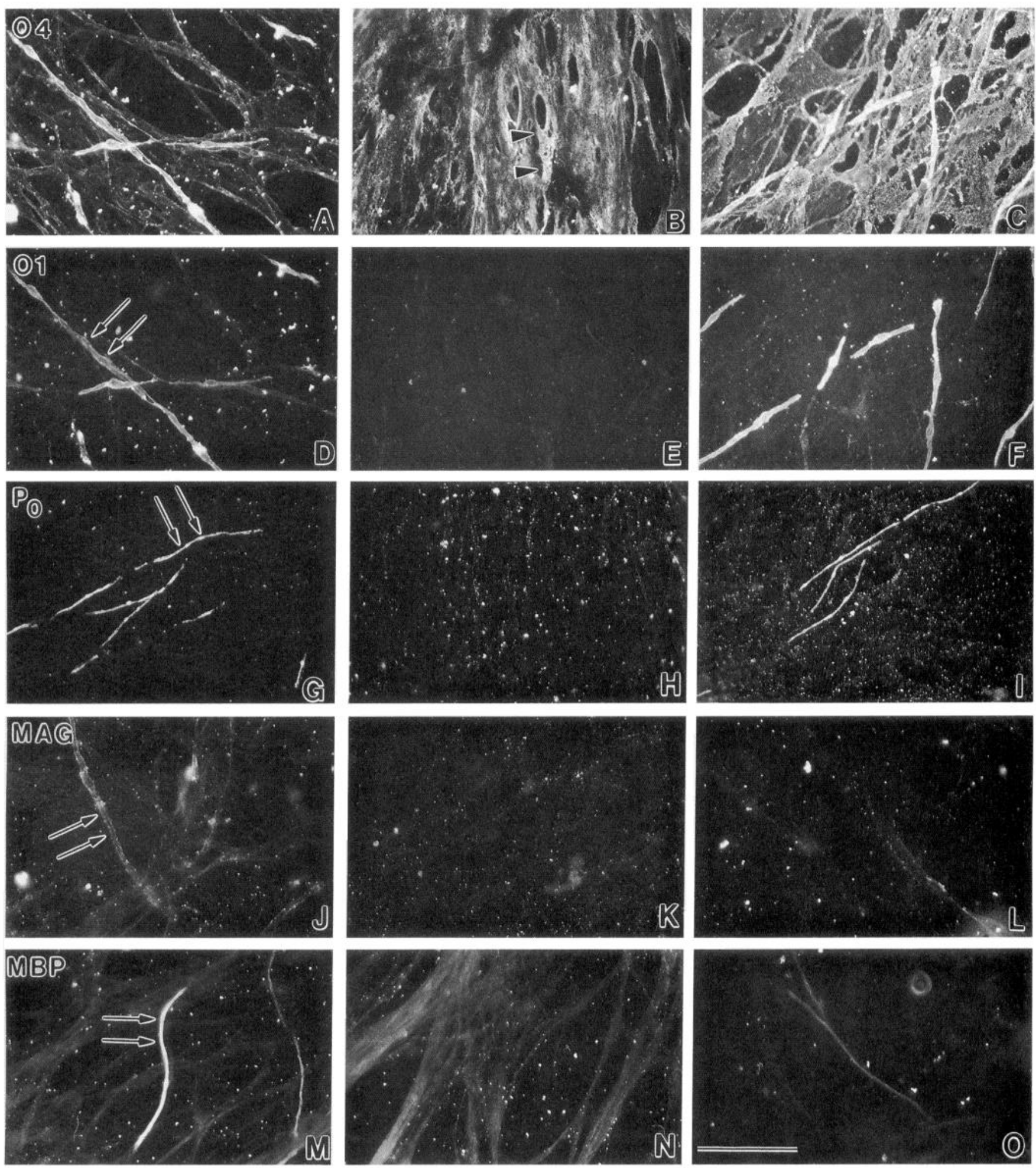

Figure 2. Myelinating Schwann cell differentiation in control $(A, D, G, J, M)$, TGF- $\beta 2$-treated $(10.0 \mathrm{ng} / \mathrm{ml})(B, E, H, K, N)$, and TGF- $\beta 2$ (10 ng/ $\mathrm{ml}$ ) combined with anti-TGF- $\beta 2$ antibody $(50 \mu \mathrm{g} / \mathrm{ml})$-treated $(C, F, I, L, O)$ neuron-Schwann cell cultures maintained in myelinating medium for 9 d. Fluorescence micrographs show immunostaining for O4 $(A, B, C), \mathrm{O} 1(D, E, F), \mathrm{P}_{0}(G, H, I), \mathrm{MAG}(J, K, L)$, and MBP $(M, N, O)$. All photographs of antibody staining of a particular epitope were taken and printed at the same exposure time and at the same magnification. Note that in cultures treated with TGF- $\beta 2, \mathrm{O} 4$ staining is abnormal (arrowhead; $A$ vs $B$ ) and that O1-, $\mathrm{P}_{0^{-}}$, MAG- and MBP-positive Schwann cells (arrows in $D, G, J, M$ vs $E, H, K, N$, respectively) are absent. Anti-TGF- $\beta 2$ antibody partially reversed these effects of TGF- $\beta 2$ on $\mathrm{O} 4, \mathrm{O} 1, \mathrm{P}_{0}$, MAG, and MBP expressions (B, $E, H, K, N$ vs $C, F, I, L, O$, respectively). Bar, $100 \mu \mathrm{m}$. 
Figure 3. Transmission electron micrographs taken from neuron-Schwann cell cultures maintained for $9 \mathrm{~d}$ in myelinating medium under control conditions $(A)$ or after treatment with TGF$\beta 2(10 \mathrm{ng} / \mathrm{ml})(B)$. Many axons are sheathed by Schwann cell processes $(*)$, and axon-Schwann cell units are surrounded by basal lamina (arrowheads) in both control and TGF- $\beta 2$-treated cultures. Note the individual axon ensheathment $(\star)$ in the TGF- $\beta 2$-treated cultures. Myelin segments $\left({ }^{* *}\right)$ are absent from cultures treated with TGF$\beta 2$. Bar, $500 \mathrm{~nm}$.
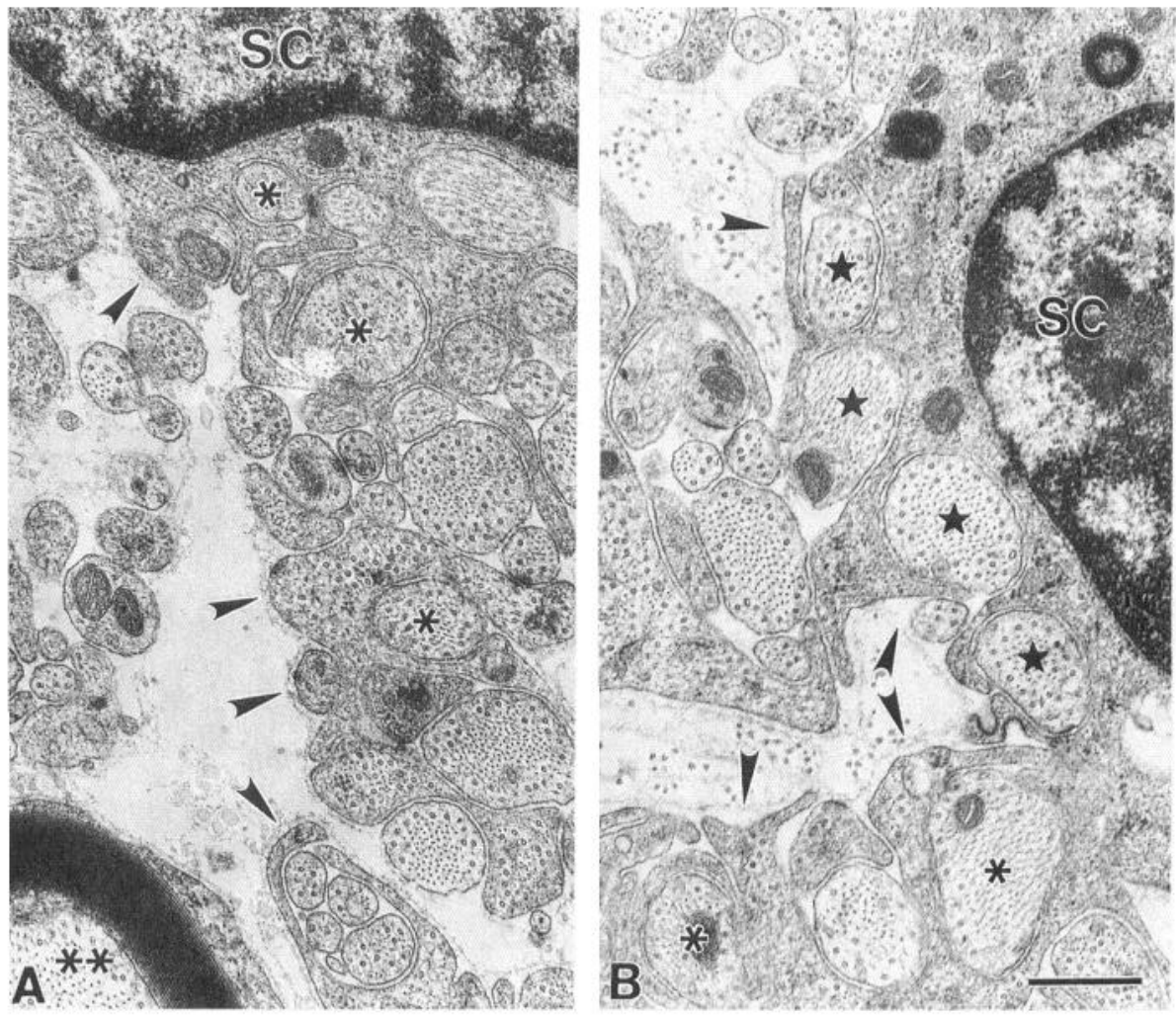

in TGF- $\beta$-treated cultures after switching to TGF- $\beta$-free medium did not result from retention of TGF- $\beta$ in the culture environment. The amount of myelin formation in cultures first maintained for $9 \mathrm{~d}$ in $\mathrm{E}$ medium (in which Schwann cells had morphologic and phenotypic characteristics similar to fully populated cultures on day 0 ) and then switched to $\mathrm{M}$ medium either containing or not containing anti-TGF- $\beta 2$ antibody was similar to the amount in cultures first maintained in $\mathrm{M}$ medium (Table 2). Taken all together, these results suggest that TGF- $\beta 2$ blocks myelination in a manner that is not readily reversible.

\section{$T G F-\beta$ blocks the expression of myelin-related molecules}

The effects of TGF- $\beta$ on Schwann cell differentiation was further characterized by evaluating the expression of differentiation stagespecific antigens by immunostaining $9 \mathrm{~d}$ after switching the cultures to $\mathrm{M}$ medium. Consistent with the inhibition of myelination by TGF- $\beta$, the expression of GC, $\mathrm{P}_{0}, \mathrm{MAG}$, and MBP was inhibited by TGF- $\beta 2(10 \mathrm{ng} / \mathrm{ml})$ (Fig. $2 E, H, K, N)$. Furthermore, the inhibition of GC expression was dose dependent; some GC-positive myelin segments were observed in cultures treated with $1 \mathrm{ng} / \mathrm{ml} \mathrm{TGF-} \beta 2$ (data not shown). The effect of TGF- $\beta 2$ on the expression of GC, $P_{0}, M A G$, and MBP was further demonstrated by partial reversal with anti-TGF- $\beta 2$ antibody (Fig. $2 C, F, I, L, O$ ). The expression of the $\mathrm{O} 4$ antigen, which does not indicate commitment to myelination or nonmyelinating ensheathment (Morgan et al., 1991), was relatively less affected by TGF- $\beta 2$. O4 staining was present, but appeared abnormally patchy on the flattened Schwann cells (Fig. $2 B$ ). In contrast, in control cultures, $\mathrm{O} 4$ staining appeared smooth and continuous, sharply delineating the spindle-shaped Schwann cells (Fig. $2 A)$. At a lower dose of TGF- $\beta 2(1 \mathrm{ng} / \mathrm{ml})$ the pattern of $\mathrm{O} 4$ immunostaining resembled that in control untreated cultures (data not shown).

\section{$T G F-\beta$ regulates the pattern of axonal ensheathment}

To better understand the effects of TGF- $\beta$ on axon-Schwann cell interactions, basal lamina formation and axon-Schwann cell relationships were assessed by electron microscopy. Since myelination depends on basal lamina formation (Eldridge et al., 1989), it was important to determine if TGF- $\beta$ affected basal lamina deposition. Basal lamina was present around all axonSchwann cell units in both control and TGF- $\beta$-treated cultures. Furthermore, its deposition appeared to be slightly increased in TGF- $\beta$-treated cultures as compared to control cultures (Fig. $3 A, B)$. Thus, the inhibition of myelination was not caused by an inhibition of basal lamina deposition.

The segregation of axons into 1:1 relationships with Schwann cells is generally considered to indicate that the Schwann cells are about to initiate the formation of myelin sheaths. We observed that concentrations of TGF- $\beta$ that completely blocked the formation of myelin had little or no effect on the segregation of axons into 1:1 relationships. Thus myelination was not blocked because of the inability of Schwann cells to engage into $1: 1$ relationships with large axons. Furthermore, the ultrastructural analysis also revealed that in the presence of TGF- $\beta$ many axons were ensheathed in the manner characteristic of mature nonmyelinated nerves; that is, multiple axons are separately ensheathed by a single Schwann cell (Fig. $3 A, B$ ). After $9 \mathrm{~d}$ in $\mathrm{M}$ medium, the presence of individual axons separately ensheathed within troughs of Schwann cell cytoplasm, which is characteristic of mature nonmyelinating ensheathment in vivo (Peters et al., 1991), was striking in the TGF- $\beta$-treated cultures (Fig. $3 B$ ). This type of ensheathment was rarely observed in control cultures under these conditions. This result suggests that TGF- $\beta$ might act to promote the nonmyelinating type of ensheathment by Schwann cells. 

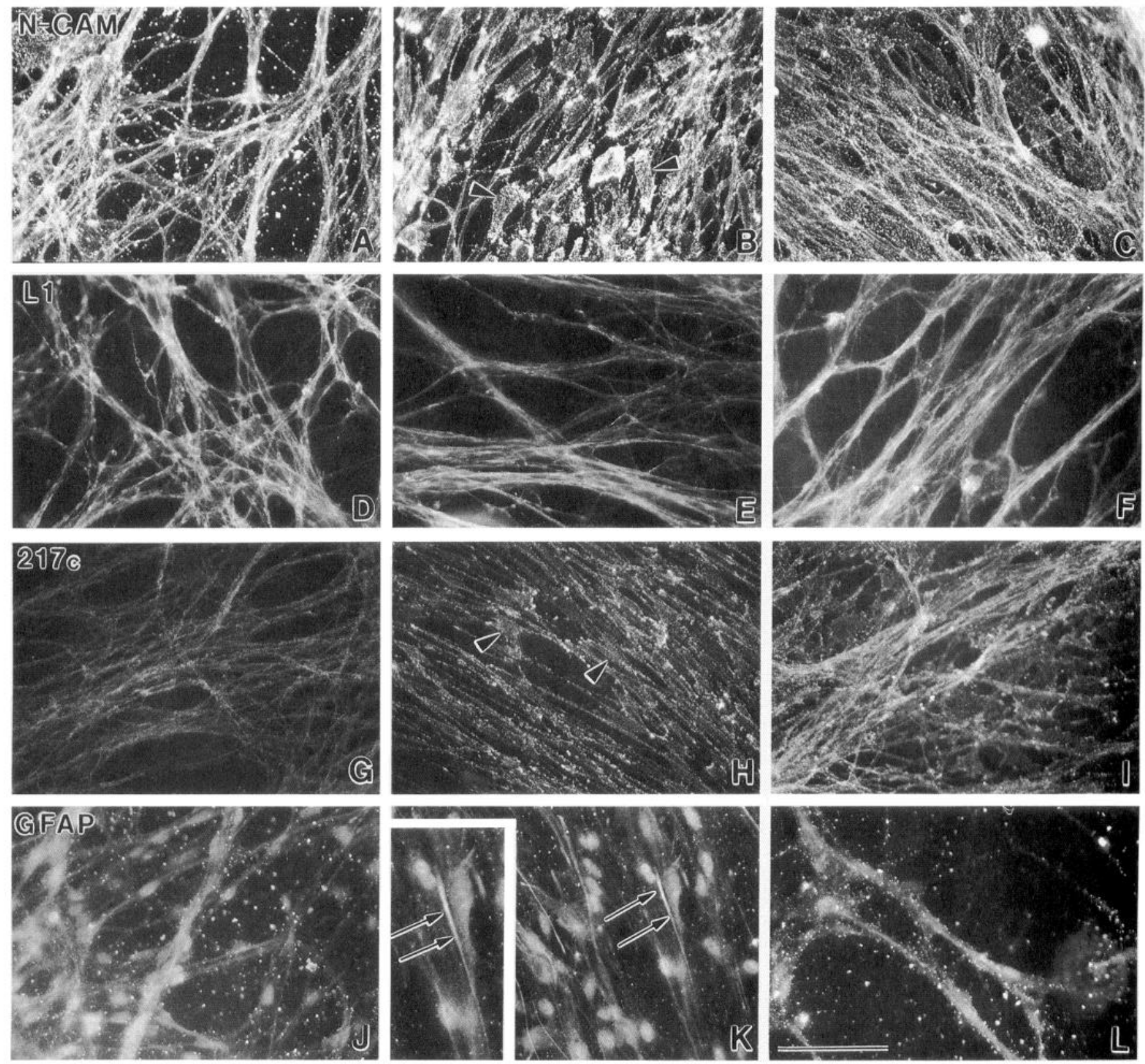

Figure 4. Nonmyelinating Schwann cell differentiation in control $(A, D, G, J)$, TGF- $\beta 2$-treated $(10 \mathrm{ng} / \mathrm{ml})(B, E, H, K)$, and TGF- $\beta 2$ (10 ng/ml) combined with anti-TGF- $\beta 2$ antibody $(50 \mu \mathrm{g} / \mathrm{ml})$-treated $(C, F, I, L)$ neuron-Schwann cell cultures maintained in myelinating medium for $9 \mathrm{~d}$. Fluorescence micrographs show immunostaining for N-CAM $(A, B, C), \mathrm{Ll}(D, E, F), 217 \mathrm{c}(G, H, I)$, and GFAP $(J, K, L)$. All photographs of antibody staining of a particular epitope were taken and printed at the same exposure time and at the same magnification. In TGF- $\beta 2$-treated cultures, N-CAM and $217 \mathrm{c}$ stainings are patchy (arrowheads in $A$ and $G$ ). Note that GFAP-positive filaments are seen in Schwann cells only in TGF- $\beta 2$-treated cultures (arrows in $K$ and inset). Bar, $100 \mu \mathrm{m}$.

\section{TGF- $\beta$ induces the expression of GFAP by Schwann cells}

To further explore the possibility that TGF- $\beta$ might promote nonmyelinating ensheathment, the expression of N-CAM, L1, NGFr, and GFAP (all molecules expressed specifically by nonmyelinating Schwann cells) was evaluated in control and TGF$\beta$-treated cultures. Although the cultures were maintained under myelinating conditions, GFAP expression, which is rarely observed under these culture conditions (V. Guénard, unpublished observations), was strongly increased by TGF- $\beta 2$ (Fig. $4 J, K$ ). In TGF- $\beta 2$-treated cultures, an average of $19.1 \%$ of the Schwann cells expressed GFAP as compared to only $1.8 \%$ in control cultures. TGF- $\beta 2$ treatment did not induce significant changes in the intensity of immunostaining for N-CAM, L1, and NGFr (Fig. $4 A, B, D, E, G, H$ ); however, these molecules were already expressed at high levels in most of the Schwann cells not forming myelin in the absence of TGF- $\beta 2$. Slight differences in the distribution of immunostaining for N-CAM and NGFr were observed (Fig. $4 A, B, G, H$ ) in that the distribution of fluorescence was patchy in the presence of TGF- $\beta 2$, but smooth and continuous in the control cultures. Partial reversal of these effects of TGF- $\beta 2$ on immunostaining patterns with anti-TGF- $\beta 2$ anti- 
body further validated the specificity of the effect of TGF- $\beta 2$ (Fig. $4 C, I, L)$.

\section{Discussion}

Current evidence suggests that both neuronal and non-neuronal signals determine the mature phenotype of Schwann cells (Aguayo et al., 1976; Weinberg and Spencer, 1976; Voyvodic, 1989; Obremski et al., 1993). In the present study we have described evidence that TGF- $\beta$, a growth factor present in DRG neurons and Schwann cells, may function as a possible regulator of Schwann cell differentiation. Our findings demonstrate that TGF- $\beta$ blocks Schwann cell myelination on DRG neurites in vitro, as well as the expression of myelin-related molecules. Furthermore, in TGF- $\beta$-trcatcd ncuron-Schwann cell cultures, Schwann cells exhibit the morphological flattening and the antigenic characteristics consistent with the nonmyelinating phenotype. In the presence of TGF- $\beta$ and under myelinating conditions the expression of N-CAM, L1, and NGFr in Schwann cells was maintained when compared to Schwann cells kept under nondifferentiating conditions. GFAP, which is rarely seen in Schwann cells maintained under our myelinating conditions, was strongly increased by Schwann cells. Finally, and most importantly, the pattern of axonal ensheathment in TGF- $\beta$-treated cultures resembled that observed in nonmyelinated nerves, a pattern rarely observed in control cultures under these conditions. These findings indicate that TGF- $\beta$ might promote the development of the nonmyelinating Schwann cell phenotype.

The mechanisms by which TGF- $\beta$ blocks myelination are unclear. Under conditions normally allowing myelination, the expression of the myclin-rclated molecules $G C, P_{0}, M A G$, and MBP was inhibited in the presence of TGF- $\beta$. Similarly, it has been reported that TGF- $\beta$ inhibits the cAMP-induced expression of $\mathrm{P}_{0}$ mRNA in isolated Schwann cells (Mews and Meyer, 1993). The blockage of myelination was not due to an inability of the Schwann cells to interact with the axons. Ultrastructural analysis indicated that Schwann cells could engage in 1:1 relationships with axons and that basal lamina was deposited, both events being required for the initiation of myelination (Webster and Favilla, 1984; Eldridge et al., 1987). An explanation for the inhibition of myelination by TGF- $\beta$ could be that TGF- $\beta$ interferes directly with intracellular signaling pathways, resulting in severe downregulation of genes encoding for myelin-related molecules. The mechanisms of action of TGF- $\beta$ on target cells have not, however, been elucidated in detail, thus making it difficult to further speculate on our findings.

In previous studies we have demonstrated that anti-Ll antibody (Wood et al., 1990b) and coculture with astrocytes (Guénard et al., 1994) also block Schwann cell myelination on DRG axons. Ultrastructural analysis showed that both anti-L1 antibody and astrocytes inhibited axon-Schwann cell interactions at a point before the segregation of axons into 1:1 relationships and thus prior to the initiation of the process of myelination. TGF- $\beta$ inhibits myelination at a step different from that blocked by anti-Ll antibody and astrocytes; in the presence of TGF- $\beta$ Schwann cells are still able to segregate axons in $1: 1$ relationships, but myelination does not proceed. It is important to note that under these conditions Schwann cells were able to perform the segregation of axons, which is generally considered a prerequisite for myelination, without detectable expression of major myelin components such as MAG. MAG has been reported to appear prior to myelination and to be necessary for the formation of 1:1 axon:Schwann cell relationships (Owens and Bunge, 1989; Owens et al., 1990). Another report indicates that MAG appears only in Schwann cells once they have formed one and a half turns of myelin around their associated axon (Martini and Schachner, 1986). MAG was not seen in cultures treated with $\mathrm{TGF}-\beta$, thus suggesting that MAG may not be necessary for the formation of $1: 1$ axon:Schwann cell relationships.

Removing TGF- $\beta$ from the culture medium did not reverse the inhibition of Schwann cell myelination. This was not due to an inability of the Schwann cells to initiate myelination during the second treatment phase since Schwann cells in control cultures never treated with $\mathrm{TGF}-\beta$ were able to form myelin. It is also unlikely that myelination was inhibited because of the retention of TGF $-\beta$, probably bound to extracellular matrix molecules such as type IV collagen (Paralkar et al., 1991) or to TGF- $\beta$ released by neurons and/or Schwann cells. If so, myelin should have formed in our cultures treated with anti-TGF- $\beta$ antibody, which was present in high amounts $(50 \mu \mathrm{g} / \mathrm{ml})$ in the culture medium.

It is unlikely that TGF- $\beta$ released by neurons and/or Schwann cells in our cultures affected our results on the inhibition of myelination by added TGF- $\beta$. This is demonstrated by our finding that anti-TGF- $\beta$ treatment did not enhance Schwann cell myelination when compared to control untreated cultures; the amount of myelin between anti-TGF- $\beta 1$ or anti-TGF- $\beta 2$ antibody-treated and untreated cultures was similar (Table $2 ; \mathrm{V}$. Guénard and P. M. Wood, unpublished observations). It is possible that any endogenous TGF- $\beta$ released by the cells in our cultures could have been biologically inactive, since TGF- $\beta$ is produced by most culturcd cclls in a latent form (Barnard et al., 1990). However, at this point we cannot definitively rule out the possibility that endogenous TGF- $\beta$ may have exerted a subtle effect on Schwann cell function.

The morphological changes in Schwann cells associated with TGF- $\beta$ treatment were consistently observed and very dramatic. Although associated with axons, Schwann cells were flattened, exhibiting a fibroblast-like morphology in the presence of TGF$\beta$. These observations suggest that $\mathrm{TGF}-\beta$ may induce cytoskeletal changes in Schwann cells. Alternatively, TGF- $\beta$ could have limited Schwann cell process extension by clustering GAP43 , a protein involved in process outgrowth, in the Golgi of the Schwann cells (Stewart et al., 1993).

TGF- $\beta$ slightly increased basal lamina deposition under our culture conditions. This could result from the stimulation of the synthesis of extracellular matrix proteins and/or the stimulation of proteinase synthesis and the inhibition of proteinase inhibitor synthesis (Rizzino, 1988; Barnard et al., 1990; Chen et al., 1993). TGF- $\beta$ stimulates the synthesis of extracellular matrix proteins, including type IV collagen (Ignotz and Massagué, 1986; Rogister et al., 1993), which is necessary for basal lamina formation and thus for Schwann cell differentiation (Carey et al., 1983, 1986). Therefore, an increase in collagen synthesis combined with the laminin added to the myelinating medium could have favored basal lamina deposition (Eldridge et al., 1989). Concomitantly, TGF- $\beta$ also decreases the secretion of tissue plasminogen activator and enhances the secretion of plasminogen activator inhibitor (Rogister et al., 1993), both of which are involved in the turnover of extracellular matrix (discussed in Monard, 1988; Pittman and Buettner, 1989).

The fact that N-CAM and Ll expressions in Schwann cells are maintained in the presence of TGF- $\beta$ also suggests a role 
for TGF- $\beta$ in peripheral nerve regeneration. It has been shown that N-CAM and LI are reexpressed by Schwann cells following transection of the sciatic nerve (Daniloff et al., 1986; Martini and Schachner, 1988) and that N-CAM and L1 on Schwann cells can bind to axonal N-CAM and L1 in a homophilic manner, promoting axonal elongation (Bixby et al., 1988; Seilheimer and Schachner, 1988). TGF- $\beta$ is present in peripheral nerves after injury (Rogister et al,, 1993; Scherer et al., 1993), possibly released in an active form by injured neurons (Rogister et al., 1993). Thus, by modulating the expression of N-CAM and L1 on Schwann cells, TGF- $\beta$ could indirectly promote axonal regeneration.

We have presented evidence that TGF- $\beta$ blocks myelination by Schwann cells and that TGF- $\beta$-treated Schwann cells exhibit the antigenic and morphological propertics characteristic of the nonmyelinating phenotype. Most importantly, in TGF- $\beta$-treated cultures the pattern of axonal ensheathment resembled that observed in nonmyelinated nerves. Finally, one antigen characteristic of the mature nonmyelinating phenotype, GFAP, was increased by TGF- $\beta$ treatment. We interpret these findings to indicate that TGF- $\beta$ might promote the development of the nonmyelinating Schwann cell phenotype.

\section{References}

Aguayo AJ, Charron L, Bray GM (1976) Potential of Schwann cells from unmyelinated nerves to produce myelin: a quantitative ultrastructural and radiographic study. J Neurocytol 5:565-573.

Barnard JA, Lyons RM, Moses HL (1990) The cell biology of transforming growth factor $\beta$. Biochem Biophys Acta 1032:79-87.

Bixby JL, Lilien J, Reichardt LF (1988) Identification of the major proteins that promote neuronal process outgrowth on Schwann cells in vitro. J Cell Biol 107:353-361.

Brockes JP, Fields KL, Raff MC (1979) Studies on cultured rat Schwann cells. I. Establishment of purified populations from cultures of peripheral nerves. Brain Res 165:105-118.

Bunge MB, Bunge RP, Carey DJ, Cornbrooks CJ, Eldridge CF, Williams AK, Wood PM (1983) Axonal and non-axonal influences on Schwann cells development. In: Developing and regenerating vertebrate nervous systems (Coates PW, Markwald RR, Kenny AD, eds), pp 71105. New York: Liss.

Bunge RP, Bunge MB, Eldridge CF (1986) Linkage between axonal ensheathment and basal lamina production by Schwann cells. Annu Rev Neurosci 9:305-328.

Bunge RP, Bunge MB, Bates M (1989) Movements of the Schwann cell nucleus implicate progression of the inner (axon-related) Schwann cell process during myelination. J Cell Biol 109:273-284.

Carey DJ, Eldridge CF, Cornbrooks CJ, Timpl R, Bunge RP (1983) Biosynthesis of type IV collagen by cultured rat Schwann cells. J Cell Biol 97:473-479.

Carey DJ, Todd MS, Rafferty CM (1986) Schwann cell myelination: induction by exogenous basement membrane-like extracellular matrix. J Cell Biol 102:2254-2263.

Chen R-H, Ebner R, Derynck R (1993) Inactivation of the type II receptor reveals two receptor pathways for the diverse TGF- $\beta$ activities. Science 260:1335-1338.

Daniloff JK, Levi G, Grumet M, Rieger F, Edelman GM (1986) Altered expression of ncural ccll adhesion molecules induced by nerve injury and repair. J Cell Biol 103:929-945.

Eccleston PA, Jessen KR, Mirsky R (1989) Transforming growth factor- $\beta$ and $\gamma$-interferon have dual effects on growth of peripheral glia. J Neurosci Res 24:524-530.

Eldridge CF, Bunge MB, Bunge RP, Wood PM (1987) Differentiation of axon-related Schwann cells in vitro: I. Ascorbic acid regulates basal lamina assembly and myelin formation. J Cell Biol 105:1023-1034.

Eldridge CF, Bunge MB, Bunge RP (1989) Differentiation of axonrelated Schwann cells in vitro: II. Control of myelin formation by basal lamina. J Neurosci 9:625-638.

Fernandez-Valle C, Fregien N, Wood PM, Bunge MB (1993) Expression of the protein zero myelin gene in axon-related Schwann cells is linked to basal lamina formation. Development 119:867-880.
Flanders KC, Ludecke G, Engels S, Cissel DS, Roberts AB, Kondaiah P, Lafyatis R, Sporn MB, Unsicker K (1991) Localization and actions of transforming growth factor- $\beta$ s in the embryonic nervous system. Development 113:183-191.

Guénard V, Gwynn LA, Wood PM (1994) Astrocytes inhibit Schwann cell proliferation and myelination of dorsal root ganglion neurons in vitro. J Neurosci 14:2980-2992.

Ignotz RA, Massagué J (1986) Transforming growth factor $\beta$ stimulates the expression of fibronectin and collagen and their incorporation into the extracellular matrix. J Biol Chem 261:4337-4345.

Jessen KR, Mirsky R (1991) Schwann cell precursors and their development. Glia 4:185-194.

Kleitman N, Wood PM, Bunge RP (1991) Tissue culture methods for the study of myelination. In: Culturing nerve cells (Banker $G$, Goslin K, eds), pp 337-377. Cambridge, MA: MIT Press.

Kumar S, Huber J, Peña LA, Perez-Polo JR, Werrbach-Perez K, deVellis J (1990) Characterization of functional nerve growth factor receptors in a CNS glial cell line: monoclonal antibody $217 \mathrm{c}$ recognizes the nerve growth factor receptor on C6 glioma cells. J Neurosci Res 27: $408-417$.

Martini R (1994) Expression and functional roles of neural cell adhesion molecules and extracellular matrix components during development and regeneration of peripheral nerves. J Neurocytol 23:1-28.

Martini R, Schachner M (1986) Immunoelectron microscopic localization of neural cell adhesion molecules (L1, N-CAM, and MAG) and their shared carbohydrate epitope and myelin basic protein in developing sciatic nerve. J Cell Biol 103:2439-2448.

Martini R, Schachner M (1988) Immunoelectron microscopic localization of neural cell adhesion molecules (L1, N-CAM, and myelin associated glycoprotein) in regenerating adult mouse sciatic nerve. J Cell Biol 106:1735-1746.

Massagué, J (1990) The transforming growth factor- $\beta$ family. Annu Rev Cell Biol 6:597-641.

Mews M, Meyer M (1993) Modulation of Schwann cell phenotype by TGF- $\beta 1$ : inhibition of P0 mRNA expression and downregulation of the low affinity NGF receptor. Glia 8:208-217.

Mirsky R, Jessen KR, Schachner M, Goridis C (1986) Distribution of the adhesion molecules N-CAM and $\mathrm{L} 1$ on peripheral neurons and glia in adult rats. J Neurocytol 15:799-815.

Monard D (1988) Cell-derived proteases and protease inhibitors as regulators of neurite outgrowth. 'Irends Neurosci 11:541-544.

Morgan L, Jessen KR, Mirsky R (1991) The effects of cAMP on differentiation of cultured Schwann cells: progression from an early phenotype $\left(\mathrm{O}^{+}\right)$to a myelin phenotype $\left(\mathrm{P0}^{+}, \mathrm{GFA}^{-}, \mathrm{N}-\mathrm{CAM}{ }^{-}\right.$, NGF-receptor ${ }^{-}$) depends on growth inhibition. J Cell Biol 112:457467.

Obremski VJ, Johnson MI, Bunge MB (1993) Fibroblasts are required for Schwann cell basal lamina deposition and ensheathment of unmyelinated sympathetic neurites in culture. J Neurocytol 22:102-117.

Owens GC, Bunge RP (1989) Evidence for an early role for myelinassociated glycoprotein in the process of myelination. Glia 2:119128.

Owens GC, Boyd CJ, Bunge RP, Salzer JL (1990) Expression of recombinant myelin-associated glycoprotein in primary Schwann cells promotes the initial investment of axons by myelinating Schwann cells. J Cell Biol 111:1171-1182.

Paralkar VM, Vukicevic S, Reddi AH (1991) Transforming growth factor $\beta$ type 1 binds to collagen type IV of basement membrane matrix: implications for development. Dev Biol 143:303-308.

Peters A, Palay SL, Webster H deF (1991) The cellular sheaths of neurons. In: The fine structure of the nervous system, neurons and their supporting cells, Third Edition (Peters A, Palay SL, Webster $\mathrm{H}$ deF, eds), pp 212-272. New York: Oxford UP.

Pittman RN, Buettner HM (1989) Degradation of extracellular matrix by neuronal proteases. Dev Neurosci 11:361-375.

Porter S, Clark HB, Glaser L, Bunge RP (1986) Schwann cells stimulated to proliferate in the absence of neurons retain full functional capability. J Neurosci 6:3070-3078.

Ratner N, Hong D, Lieberman MA, Bunge RP, Glaser L (1988) The neuronal cell-surface molecule mitogenic for Schwann cells is a heparin-binding protein. Proc Natl Acad Sci USA 85:6992-6996.

Ridley AJ, Davis JB, Stroobant P, Land H (1989) Transforming growth factors- $\beta 1$ and $\beta 2$ are mitogens for rat Schwann cells. J Cell Biol 109: 3419-3424.

Rizzino A (1988) Transforming growth factor- $\beta$ : multiple effects on cell differentiation and extracellular matrices. Dev Biol 130:41 1-422. 
Rogister B, Delrée P, Leprince P, Martin D, Sadzot C, Malgrange B, Munaut C, Rigo JM, Lefebvre PP, Octave J-N, Schoenen J, Moonen $G$ (1993) Transforming growth factor $\beta$ as a neuronoglial signal during peripheral nervous system response to injury. J Neurosci Res $34: 32-43$.

Salzer JL, Bunge RP, Glaser L (1980) Studies of Schwann cell proliferation. III. Evidence for the surface localization of the neurite mitogen. J Cell Biol 84:767-778.

Scherer SS, Kamholz J, Jakowlew SB (1993) Axons modulate the expression of transforming growth factor-betas in Schwann cells. Glia $8: 265-276$

Schubert D (1992) Synergistic interactions between transforming growth factor beta and fibroblast growth factor regulate Schwann cell mitosis. J Neurobiol 23:143-148.

Seilheimer B, Schachner M (1988) Studies of adhesion molecules mediating interactions between cells of peripheral nervous system indicate a major role for $\mathrm{Ll}$ in mediating sensory neuron growth on Schwann cells in culture. J Cell Biol 107:341-351.

Sporn MB, Roberts AB (1992) Transforming growth factor $\beta$; recent progress and new challenges. J Cell Biol 119:1017-1021.

Stewart HJS, Jessen KR, Mirsky R (1993) After TGF- $\beta$ treatment GAP-43 is localised to the Golgi area of the Schwann cell. Soc Neurosci Abstr 19:879.
Unsicker K, Flanders KC, Cissel DS, Lafyatis R, Sporn MB (1991) Transforming growth factor beta isoforms in the adult rat central and peripheral nervous system. Neuroscience 44:613-625.

Voyvodic JT (1989) Target size regulates calibre and myelination of sympathetic axons. Nature 342:430-433.

Webster H deF, Favilla JT (1984) Development of peripheral nerve fibers. In: Peripheral neuropathy, 2d ed (Dyck PJ, Thomas PK, Lambert EH, Bunge RP, eds), pp 329-359. Philadelphia: Saunders.

Weinberg HJ, Spencer PS (1976) Studies on the control of myelinogenesis, part 2: evidence for neuronal regulation of myelin production. Brain Res 113:363-378.

Wood PM, Bunge RP (1975) Evidence that sensory axons are mitogenic for Schwann cells. Nature 256:662-664.

Wood PM, Williams AK (1984) Oligodendrocyte proliferation and CNS myelination in cultures containing dissociated embryonic neuroglia and dorsal root ganglion neurons. Dev Brain Res 12:225-241.

Wood PM, Moya F, Eldridge CF, Owens G, Ranscht B, Schachner M, Bunge MB, Bunge R (1990a) Studies of the initiation of myelination by Schwann cells. Ann NY Acad Sci 605:1-14.

Wood PM, Schachner M, Bunge RP (1990b) Inhibition of Schwann cell myelination in vitro by antibody to the $\mathrm{L} 1$ adhesion molecule. J Neurosci 10:3635-3645. 